\title{
Da Herança à Localização Cerebral: sobre o Determinismo Biológico de Condutas Indesejadas
}

SANDRA CAPONI "

Analisamos os argumentos utilizados, em dois momentos diferentes do século XX, para justificar o recurso a explicações biológicas de condutas consideradas como socialmente indesejadas. Referimo-nos, inicialmente, aos estudos realizados pelos higienistas de início do século, cujas explicações estavam centradas no caráter orgânico e inato dos desvios, para continuar logo com os recentes estudos da neurociência que se propõem a localizar as condutas nas sinapses inadequadas e nas explicações referidas a deficiências químicas do cérebro.

Palavras chave: localização cerebral; herança; determinismo biológico.

Recebido em: 31/08/2006.

Aprovado em: 15/02/2007. 
A tendência de construir explicações biológicas para comportamentos considerados socialmente indesejados, tais como o alcoolismo, o sentimento de tristeza ou melancolia (que hoje chamamos depressão), a infância problemática (que hoje recebe o diagnóstico de DDA - Distúrbio de Déficit de Atenção), ou a violência, caracterizou grande parte do discurso da Higiene e da Medicina Legal no final do século XIX e início do XX.

Sabemos que o determinismo biológico de início do século XX insistia no caráter orgânico e hereditário dos comportamentos considerados indesejados. Mas essas explicações, longe de desaparecerem, parecem ter adquirido poder ainda maior no final do século XX e início do XXI. Assim, a partir dos anos 1980, podemos ver reaparecer, com força inesperada, estudos que, a partir das Neurociências, da Genética ou da Sociobiologia, retomaram as antigas preocupações referidas às "condutas indesejadas", criando novas estratégias explicativas que reiteram muitas das teses do determinismo biológico clássico.

Essas novas estratégias deterministas afirmam, segundo Lewontin et al., que:

Os fatos biológicos são ontologicamente anteriores e responsáveis pelas características das condutas ou dos fenômenos existenciais. Assim, se a bioquímica cerebral foi alterada através de uma determinada patologia, então essa alteração deve corresponder a algum tipo de predisposição genética, que teria sido a causa (ainda que indireta) do transtorno (LEWONTIN; ROSE; KAMIN, 2003, p. 249).

A persistência de um século nas explicações biológicas dos fenômenos existenciais não pode ser facilmente reduzida à história da progressiva conquista na localização de lesões orgânicas, distúrbios cerebrais ou deficiências químicas, nem à tão procurada identificação dos genes responsáveis pelas patologias ou comportamentos. As patologias associadas a comportamentos (GORI, 2005; MICHAUD, 2000) possuem ainda hoje, como ocorreu no início do século XX, diagnósticos ambíguos e imprecisos, terapêuticas de eficácia duvidosa e efeitos colaterais imprevisíveis.

É conhecida a eficácia social que possui este tipo de explicação: aquilo que tem uma origem orgânica identificável poderá ser resolvido com a terapêutica apropriada, seja ela farmacológica ou cirúrgica, conforme as exigências das mudanças tecnocientíficas. Hoje é possível afirmar que uma droga capaz 
substituir o déficit de dopamina (a ritalina) fará com que as crianças diagnosticadas com déficit de atenção modifiquem sua conduta e permaneçam obedientes por um período que oscila entre quatro e 24 horas, desconsiderando a multiplicidade de fatores pedagógicos, sociais, familiares que podem afetar a criança nesse momento. Multiplicam-se, assim, os estudos de laboratórios dedicados à procura por aquilo que Lewontin chamou de "bala mágica", uma medicação capaz de agir com precisão sobre os comportamentos que precisam ser mudados, e o Prozac não é mais que um dos muitos exemplos.

Mas a desconsideração dos fatores sociais, que caracteriza a maior parte dos estudos de laboratório, não nos autoriza a reduzir todos os nossos sofrimentos e aflições a explicações que se esgotam na idéia da "construção social". Em muitos casos, a perspectiva adotada pelas Ciências Humanas se limita à inversão das explicações biológicas e à completa negação de qualquer substrato orgânico para os fenômenos humanos. Então, os fenômenos sociais mais diversos são pensados como efeitos de "construções sociais", desde a criminalidade e a violência, até a anorexia, a esquizofrenia ou as mais variadas epidemias (a lepra ou a peste, por exemplo). Desse modo, a dimensão biológica, orgânica, o que reconhecemos como nossa corporeidade, parece ter-se reduzido até o ponto de desaparecer.

Será necessário tentar compreender de que modo se articularam historicamente as duas dimensões que formam parte da condição humana, nossa corporeidade que nos conduz inevitavelmente à velhice e ao sofrimento, e a complexa estrutura social na qual estamos inseridos. Mas essa compreensão exige uma análise detalhada dessa diversidade de fenômenos, que Lewontin chamou de "existenciais". Deveremos considerar que não existe o mesmo tipo de articulação entre as dimensões "somática" e "social" quando falamos de obesidade, criminalidade ou déficit de atenção.

Para compreender os diversos modos como foi pensada essa articulação, analisaremos os argumentos que foram utilizados em dois momentos diferentes do século XX, para justificar o recurso a explicações biológicas das condutas. Faremos breve referência aos estudos realizados pelos higienistas de início do século, cujas explicações estavam centradas na hereditariedade e, consequientemente, no caráter orgânico e inato dos desvios, para continuar com os recentes estudos da Sociobiologia e da Neurociência, que se propõem a localizar os sintomas no corpo: seja nas sinapses inadequadas, na determinação genética ou nas deficiências neuroquímicas. 
Observando essa história, veremos que a antiga preocupação por localizar as lesões no corpo dos doentes, que possibilitara a construção da anátomo-clínica, pode ser hoje recuperada e aplicada não só às patologias orgânicas, mas também às patologias mentais ou comportamentais. Os diagnósticos por imagem parecem permitir a localização de lesões no cérebro, do mesmo modo que podemos localizar uma lesão no pulmão ou no fígado. Em muitos casos, estas explicações químicas e neurobiológicas dos comportamentos se apresentam como a contraface da crescente procura por genes específicos que, segundo se afirma, seriam a causa direta de tais comportamentos.

Nesse marco explicativo deveremos inserir, também, os estudos da Sociobiologia iniciados por Wilson, em 1976. A partir dos anos 1980, esses estudos se expandiram e consolidaram, dando um novo impulso à tese que supõe que é possível falar de universais sociais humanos geneticamente determinados, estabelecidos a partir de um processo de seleção natural. Entre esses universais, tem-se falado de supostos genes determinantes do conformismo, do altruísmo, da violência, etc. Todos esses fatos pareceriam contribuir, finalmente, para fechar o puzzle que começara a se montar com o discurso dos higienistas do início do século e que se consolidou, pouco a pouco, no decorrer do século XX, até se transformar em hegemônico: a determinação biológica dos comportamentos.

Esse discurso hegemônico teve, no entanto, fortes e lúcidos críticos e opositores, que não se limitaram a contrapor ao determinismo biológico os supostos do determinismo social ou cultural. Sem reduzir toda e qualquer explicação a "construção social", eles se preocuparam em compreender as complexas interações existentes entre o biológico e o social. Dentre eles, poderíamos mencionar os trabalhos de Canguilhem (1993, 2001), Lewontin, Rose \& Kamin (2003), Changeaux (2003), Hacking (1999), Dagognet (1998), Jacquard (2005), Fox-Keler (2001) ou Fagot-Lageault (2002). Esses autores, entre muitos outros, estão interessados em articular as duas dimensões que, para os deterministas biológicos e culturais, representam duas realidades ontológicas e epistemológicas em conflito.

Como afirmam Lewontin et al., devemos insistir em que uma compreensão plena da condição humana (e das diferenças humanas) exige uma interação do biológico e do social que as considere como esferas relacionadas de modo dialético, um modo que distinga epistemologicamente entre níveis de explicações referidos ao indivíduo e níveis 
Da Herança à Localização Cerebral: sobre o Determinismo Biológico...

de explicações relativos ao social, sem que se destruam mutuamente ou se negue a existência de um deles (LEWONTIN; ROSE; KAMIN, 2003, p. 96).

Ainda que essa exigência de Lewontin et al. (2003) tenha sido enunciada há mais de 20 anos, ela permanece absolutamente atual. Evelyn Fox-Keller (2001), referindo-se ao debate aberto em 1984 com a publicação de "Não está nos genes", de Lewontin, Rose e Kamin, dirá que a biologia do desenvolvimento nos ajuda a compreender que a ação dos genes sobre nosso organismo está longe de ser simples e linear, e que a crítica de Lewontin ao determinismo genético se mostrou absolutamente atual e pertinente. Ian Hacking, por sua vez, afirmou, em 2006: "Após o entusiasmo inicial no determinismo, quase todo mundo ficou ciente de que todo 'não está nos genes', para lembrar a importante polêmica de Lewontin, Rose e Kamin” (HACKING, 2006, p. 6).

No entanto, o fato de que a crise do determinismo biológico já tenha sido vislumbrada em 1984, não garante que os pesquisadores ou as indústrias farmacêuticas tenham desistido de procurar respostas biológicas para os fatos sociais. As explicações deterministas hoje enunciadas não são idênticas àquelas que foram defendidas no século XIX. Porém, entre essas estratégias explicativas existem peculiaridades, diferenças e analogias que podem nos auxiliar a melhor compreender nosso presente.

Em linhas gerais, podemos destacar duas modalidades diferentes de formular as explicações biológicas das condutas ou dos fenômenos existenciais. A primeira foi representada pelos higienistas e alienistas de início do século XX; a segunda, pela Neurobiologia, Genética e Sociobiologia, que aparecem como marco obrigatório de referência a partir das últimas décadas do século $\mathrm{XX}$.

Em finais do século XIX e início do XX, os higienistas, médicos e psiquiatras centravam as explicações de condutas consideradas socialmente indesejadas na hereditariedade e, conseqüentemente, no caráter orgânico e inato dos desvios. Neste caso, tratava-se de um determinismo biológico sem localização precisa.

Perante a impossibilidade que os primeiros estudos neurológicos encontraram para localizar lesões orgânicas no cérebro que pudessem explicar os desvios de comportamento, a Psiquiatria construirá um grande corpo, um corpo ampliado, que é o da família afetada por patologias. Desde o século XIX e durante grande parte do século seguinte, o discurso dos higienistas, psiquiatras e médicos vai se referir ao caráter hereditário dos comportamentos. 
Na medida em que não se pode achar no corpo do doente um substrato orgânico para sua doença, trata-se de encontrar na família certo número de eventos patológicos que, embora sejam de outra natureza (se seu pai era apoplégico, ou se a mãe tinha reumatismo, ou se possui ou não um primo idiota), referem-se à existência de um substrato material patológico (FOUCAULT, 2003, p. 237).

Já nas décadas de 1820-40, quando ainda não existiam estudos sobre a herança de patologias, a preocupação com as diferentes doenças que afetavam ou tinham afetado os ascendentes familiares era um dos itens essenciais dos interrogatórios psiquiátricos. A funcionalidade dessas atribuições não estava vinculada com as doenças que hoje chamamos hereditárias, mas sim com os estudos de comportamentos e condutas indesejadas. A herança se configura como o modo de doar um corpo (um substrato orgânico) às patologias e condutas que não têm uma localização precisa.

A segunda forma de determinismo biológico, que surge na última metade do século XX e permanece até hoje, tem o objetivo preciso de localizar as lesões no cérebro. Já não será necessário criar um corpo fantasmagórico ou ampliado que inclua as "taras" familiares. A busca por disfunções cerebrais, que um século antes havia fracassado, parece ter adquirido uma precisão e força inesperadas para explicar os comportamentos humanos em geral, e as condutas indesejadas, em particular.

As explicações químicas, a complexidade das diversas funções do cérebro, as explicações neurobiológicas dos comportamentos que falam de sinapses inadequadas, de falta de dopamina ou serotonina, as explicações genéticas e a crescente procura por genes responsáveis por diversas patologias orgânicas ou comportamentais se sucedem nas mais prestigiosas revistas científicas, como Jama ou The Lancet. Vejamos brevemente dois exemplos recentes:

1) A determinação biológica da moralidade: A revista de divulgação científica La Recherche publicou, no mês de junho de 2006, um artigo de Silvie Berthoz, com o sugestivo nome de "Le cerveau moral". Nesse escrito, lemos que publicações científicas de prestígio como Science ou Nature publicaram recentemente artigos referidos ao tema. Eles afirmam que a partir da sofisticação dos estudos de imagem cerebral, é possível localizar as regiões do cérebro que são ativadas no momento de realizar julgamentos morais. Para eles, os julgamentos morais estariam diretamente vinculados com uma série de emoções 
morais (de condenação aos outros, de empatia, de altruísmo). Quando os sujeitos de pesquisa são submetidos à observação de imagens ou relatos com conteúdo moral, os estudos de imagem cerebral revelam que se ativa um conjunto de estruturas cerebrais: o córtex orbitofrontal e o lóbulo temporal anterior (BERTHOZ, 2006, p. 46). Sentimentos e, conseqüentemente, comportamentos que revelam medo, culpa, piedade ou ódio, poderiam ser localizados com os equipamentos de ressonância magnética precisos, do mesmo modo como podemos localizar a lesão no pulmão de um doente de câncer. O sonho de Charcot parece por fim realizado.

2) A determinação biológica da depressão: em março de 2006, Social Science \& Medicine publica o artigo "Social determinants of diagnostic levels in depression", de Susan McPherson. A autora adota uma perspectiva crítica sobre as idéias hegemônicas que afirmam a determinação biológica da depressão e, para sustentar sua crítica, analisa as mudanças ocorridas nas diferentes versões do DSM: II, III, IIIR, IV. Isto é, analisa as mudanças ocorridas na percepção social e institucional da depressão desde 1966 (ano em que pela primeira vez foi utilizado o termo na Psiquiatria) até 2002. Entre os anos 1966 a 1973, a depressão é pensada a partir de causas existenciais e as referências terapêuticas estão dadas fundamentalmente pela terapia psicanalítica. Entre os anos 1977 a 1984, existe uma luta entre o poder psiquiátrico e a psicanálise, começam a ser receitados os antidepressivos tricíclicos utilizados até hoje, ainda que com efeitos colaterais e também o Lethio, até então utilizado só para psicoses maníaco-depressivas. Entre os anos 1985 a 1992 os neurotransmissores começam a ser considerados responsáveis pela depressão, e o psiquiatra ganha terreno perante o psicanalista. Entre os anos 1993 a 2000, reforça-se a idéia de localização biológica e se identifica o déficit de serotonina como responsável e, logo, os recapturadores de serotonina (SSRIs), como o Prozac, aparecem como a solução esperada. McPherson inicia o artigo afirmando que "Nos últimos duzentos anos, as classificações médicas se fundamentaram na procura de lesões patológicas; poder definir uma referência física ou orgânica é o modo de ganhar consenso em certas doenças específicas" (MCPHERSON, 2006, p. 54). A classificação psiquiátrica está tradicionalmente fundamentada em sintomas, mais do que em localização orgânica; no entanto, o desenvolvimento da indústria de psicotrópicos e antidepressivos é a contraface do crescente poder da Psiquiatria e de sua aliança com a Neurociência para localizar no cérebro a deficiência que causa o quase maciço fenômeno da depressão. 
Como podemos observar com esses exemplos, ainda que a crise do determinismo biológico já tenha sido apontada em 1984, este resiste vigoroso, não só na revista Veja ou no Fantástico, más também em publicações prestigiosas, como a Science.

Para concluir, é necessário reconhecer que a crítica ao determinismo biológico não garante, por si própria, um esclarecimento sobre a complexa relação existente, nos diferentes âmbitos dos fenômenos humanos, entre fatores biológicos (sejam eles genéticos ou neurológicos) e fatores sociais.

Pensemos nas múltiplas pesquisas dedicadas a procurar "o gene da homossexualidade" ou o "gene do alcoolismo". Essas pesquisas demonstram a dificuldade em articular as duas dimensões da condição humana. Como foi analisado por Hacking (2006):

Aqueles que procuram o gene do alcoolismo acreditam que a descoberta permitirá provar que o alcoolismo é uma doença. Aqueles que procuram o gene da homossexualidade acreditam que a descoberta permitirá provar que a homossexualidade não é uma doença. Essa contraditória oposição nos lembra que ainda estamos numa face adolescente no que diz respeito a compreender a "biossociabilidade", isto é, os modos possíveis de interação entre os fenômenos biológicos e os fatos sociais.

\section{Referências}

BERTHOZ, S. Les traces cerebrales de la morale. La Recherche, n. 398, p. 46-50, 2006.

CANGUILHEM, G. Écrits sur la medicine. Paris: Seuil, 2001. . Le normal et le pathologique. Paris: PUF, 1993.

CHANGEUX, J. P. Gènes et culture. Paris: O. Jacob, 2003.

DAGOGNET, F. Qu'est-ce que la physiologie selon Canguilhem? In: ROUDINESCO, E. et al. (Org.). Actualité de le normal et le pathologique. Paris: Institut Synthélabo, 1998. p. 85-95.

FAGOT-LAGEAULT, A. Comme vient-on à la philosophie des sciences? In: BADIEU, A.; DAGOGNET, F. (Org.). La vocation philosophique. Paris: Centre Pompidou, 2002. p. 78-95. 
FOUCAULT, M. Le pouvoir psyquiatrique. Paris: Gallimard, 2003.

FOX-KELLER, E. Lenguaje y vida. Buenos Aires: Manantial, 2001.

GORI, R.; DEL VOLGO, M.-J. La santè totalitaire. Paris: Denoel, 2005.

HACKING, I. Biosocial identity: Which biology? Whose society? In:

Biosocial for Columbia, 2006. No prelo.

. The social construction of what? Cambridge: Harvard University Press, 1999.

JACQUARD, A.; KAHAN, A. L'Avenir n'est pas écrtit. Paris: Bayard, 2005.

LEWONTIN, R.; ROSE, S.; KAMIN, L. No está en los genes: racismo, genética e ideología. Barcelona: Crítica, 2003.

McPHERSON, S. Social determinants of diagnostic labels in depression. Social Science \& Medicine, n. 62, p. 50-58, 2006.

MICHAUD, Y. Des modes de subjectivation aux techniques de soi. Rev. Cité, Paris, v. 2, p. 11-40, 2000.

WILSON, E. Sociobiología, la nueva síntesis. Barcelona: Omega, 1980.

\section{NOTA}

- Doutora em Filosofia; professora no Departamento de Saúde Pública da Universidade Federal de Santa Catarina; pesquisadora de CNPq. Endereço eletrônico: sandracaponi@ newsite.com.br. 


\section{From Heritage to Cerebral Localization: on the Biological} Determinism of Undesired Conducts

The article analyzes the arguments used in two distinct moments of the 20th century, to justify the use of biological explanations for conducts considered as socially undesirable. Firstly we refer to studies of hygienists in the early century, whose explanation were centered on the organic and innate character of deviations, then we analyze the recent studies in the neurosciences which try to locate these conducts in inadequate synapses and in explanations related to chemical cerebral deficiencies.

Key words: cerebral localization; heritage; biological determinism. 